\title{
E-Learning: Perspective, Relative Merits \& Key Technological Emerging Trends in India
}

Seema Rani, Research Scholar, Department of Engineering and Technology, Tantia University, Sri

Ganganagar (Rajasthan) - India, simranaansal314@gmail.com

Dr. Sanjay Tejasvee, Assistant Professor, MCA Department, Engineering College Bikaner

(Rajasthan) - India, drsanjaytejasvee@gmail.com

\begin{abstract}
Due to several benefits of electronic (e)-learning, learner are very much interested to participate at every level of education in India, e-learning have the enough potential to transform with enhancement the entire education system So, it has become one of the most popular and topic towards researchers and played very significant role in the current scenario of transform education in India. Usually, traditional learning is very tedious, restricted to classroom only, fixed time learning, high cost and need a appropriate setup of building structure with many other essential things while in e-learning technique teaching become interactive and can be viewed at multiple places in same and dissimilar time by using information and communication technology (ICT) tools and latest trends of teachings methods. In India also elearning plays a significant role to create academic, professional and researchable environment which is better for growth of the nation and intelligence making in the societies. This paper will express the perceptions, techniques, advantages, disadvantages, research trends of e-learning and various latest initiatives taken towards e-learning in
\end{abstract} India.

Keywords - Academic, E-Learning, Enhancement, ICT, Interactive, Professional, Researchable, Traditional Learning and Transform.

\section{INTRODUCTION}

Learning can be defined as an communication between a learner and educator within an environment, leading to a planned outcome. Learning is measureable and relatively permanent change in behaviour through experience, instruction or study. Due to ICT, e-learning is switching the entire scenario of education in very high speed. Elearning makes both learning and teaching interesting. Basically, e-learning is an incredibly huge term which includes various techniques teaching as well as learning based on ICTs. It is a perfect combination of skills and technology.

Learning is immensely powered by progression of ICTs and advanced digital mediums. Learning using these latest mediums is referred as e-learning which enable the person who find it difficult to be present physically in classroom to access education and can maintain and support huge numbers of learners who can be administered via an online method. [1] Learning can be defined as transfer of knowledge from teachers to learners.[2]

E-Learning contains a lot of different things and it is understood differently by players with very different roles. E-Content Report (2004) expresses e-learning as an umbrella which describes every kind of learning that enhanced or depends on electronic communication medium by utilize the most recent tools of ICT. ELearning can be said as a generic term which covering a large set of ICT based processes, applications, consisting computer based learning, web based learning, virtual classrooms, networking and digital collaboration. Finally, e-learning can be defined as a digitally delivered interaction based learning. E-learning can be also called as online learning, computer-assisted instruction, distributed learning, Internet based learning or web based learning [4]. In today's era, the way education is delivered has changed with the use of new multimedia means like videos and audios making it captivating and alluring [5]

\section{BENEFITS OF E-LEARNING}

The reception of E-learning in instruction, particularly for higher instructive establishments has a few advantages and given its few focal points and advantages, e-learning is considered among the best strategies for training. [6][7][8] A few examinations and creators have given advantages and points of interest got from the appropriation of elearning innovations into institutes. [9]E-learning improves the adequacy of information and capabilities by means of straightforward entry to an enormous measure of data[10][11]Theutilization of elearning offers the institutio ns the same adaptability of time much like their understudi 
es or graduates and spot of conveyance or receipt of as indicated by learning data.[12]

Deal that making learning resources available electronicaly results inbetter learning outcomes merely for specific form s of aggregate assessment. The following advantages elearning defined by the several authors by taking note of that the capacity of e-figuring out how to survey the understudies or students as they learn. While at same time extend their training experiences by $\mathrm{m}$ ethod of logical intuition to network instruction instructors social assorted variety and globalization and remove limits of place and time.

\section{A. Global Accessibility}

E-learning severs vast accessibility to learning resources and enables students, learners teachers, educators, and groups to be join at single region through Internet and tools of ICTs. E-learning offers chance to get right of entry to to a variety of kinds of libraries at world-wide and verbal exchange by chat and e-mail with useful resource persons. It additionally permits us to make use of quite a few e-repositories reachable at global level. As a summary, we can say e-learning eliminated generally all restrictions and serves restricted $\&$ limitless resources of understanding in of the modern society.

\section{B. Provide education at low cost}

Serving education and knowledge to everyone at low cost is a very big issue in India. According to the population of India researchers, students and educators needs feasible and lower price solution to get knowledge, training and share the skills closer to a huge range of persons. Elearning the possible system where training can be supplied in the direction of massive number of students or learners at reasonable charges

\section{Flexibility}

In e-learning framework, students and instructor can pick of their own season of educating and learning according to accessible their timetable while in customary training framework timing and spot are constantly fixed.

\section{Substance of the course}

In e-learning, students can watch substance of the course and other required material at whenever. In this way, elearning is totally another revaluation over customary learning framework and these days assessments are additionally directing on the web so it's very show and exactness with straightforwardness of checking of assessment utilizing ICT instruments and applications, Even those some test is lead according to the selection of understudies implies understudies can choose the day and time of assessment.

\section{E. Quick Accession}

snappy promotion to expertise assets is most significant attribute of e-realizing where boundless e-assets accessible just in a couple of moments seconds and accessible for sensible examination of numerous substance on same subject.

\section{F Delivery of nature of instruction:}

It can be seen that quality assets of aptitudes and information are accessible just at certain establishments just and it's impractical to convey great nature of training at all over the place yet by e-learning virtual classes it can feasible for instance e-talks of IIT's, NIT's and presumed organization's teachers are accessible on electronic medium.

\section{G E-learning can likewise helps to remove obstacles towards progress}

By serving inventive way of drawing in students and empowering with motivating everybody to show their instructive potential, Educators and understudies can without quite a bit of a stretch re-try propelled learning advantages for suit pace and level, fitting to any learning style and limit. E-learning is essentially an online system of instructional preparing.

$H$. E-learning can give an individualized learning, experience for all understudies, including the people who are debilitated, phenomenally gifted, have unprecedented instructive program or adjusting needs or who are remote or away from their standard spot of learning.

I. E-learning can energize increasingly broad premium and progressively charming access to further and propelled training by making the opportunity to start learning and to pick courses and support according to the understudies' needs.

$J$. E-learning can help understudies with finding the course they need, with a predictable change to period of their getting, remembering for the web application or selection and an electronic plan of their making sense of how to take with them.

\section{DRAWBACKS OF E-LEARNING}

Be that as it may, E-Learning can improve the preparation quality however paying little heed to the focal points that it has when grasped in preparing and have a few preventions and bothers. [6][13][14][15] E-Learning is simply just an assistance device for existing systems for learning. There are following disadvantages of e-taking in which have abridged from a few creators purpose of perspectives and thought: [7] [8] [16][17][18] 
A. Since tests for evaluations in e-learning are possibly completed with the use of middle person, it will be problematic, if not hard to control or direct horrendous activities like cheating.

B. With respects to advance in social capacities of understudies, e-learning as a procedure may have a negative effect. The understudies regardless of the way that may have magnificent data in scholastics, they might not have the necessary capacities to pass on their picked up data to others. E-learning as a procedure for preparing makes the understudies experience thought, remoteness, similarly as nonappearance of cooperation or association. It right now an outstandingly strong inspiration similarly as capacities with to the organization of time to diminish such effects.

C. Regarding clarifications, offer of explanations, similarly as interpretations, the e-learning methodology might be less suitable that the customary procedure for learning. The learning strategy is significantly less complex with the usage of the very close involvement in the teachers or educators.

D. E-learning may in like manner brief blockage or generous use of specific destinations. This may understand unanticipated costs both in time and money burdens. Elearning may in like manner rot associations' activity socialization work and moreover the activity of teachers as the administrators of the strategy of preparing. E-learning may in like manner apparently be misled to robbery and composed misrepresentation, slanted by inadequate decision capacities, similarly as the straightforwardness of reorder.

F. Absence of notable structure and routine may take becoming acclimated to Students may feel bound or miss social correspondence. Educator may not commonly be available on demand. Slow or faulty Internet affiliations can be baffling. A couple of courses, for instance, regular hands-on courses can be difficult to replicate.

G. Restrictions of e-learning Computer capability and access to outfit: One of the tremendous requirements of ediscovering that a coach/understudy should be PC instructed he/she should know PC. In the occasion that understudy/coach doesn't know PC he/she can't pick up from e-learning procedure.

H. An understudy who focuses on e-learning framework should act normally pushed and educate considering the way that no one is there to state is centered around your assessment. Inclination towards all around educated understudies over nontechnical understudies and instructors nonappearance of data and experience to oversee virtual teacher understudy collaboration.

J. Additionally not all fields or control can use the elearning framework in preparing. For instance the completely coherent fields that fuse rational can't be suitably thinks through e-learning. Investigates have fought that e-learning is more reasonable in humanism and humanities than the fields, for instance, clinical science and medication store, where there is the need to make sensible capacities.

\section{DIFFERENT RAW BACKS OF E-LEARNING}

E-learning gives the student a large portion of the things he wants to joke himself. It doesn't confine the student with anything except if and until appropriate asset is accessible at student and simultaneously accessibility of the data made by the somebody who has just comprehended the necessity and reason for student's advantage. Some electronic gadgets utilized for e-learning are PC, Television(TV), cell phone, PDA, tablet, individual advanced assistant and so on., The mechanical tends of eadapting today are enormous and creating with quick pace. Some new example is creating to give extraordinary learning systems to the understudies among the standard mechanical e-learning designs these are some recorded as follows:

\section{A. User warmth of e-learning apparatuses and stages}

Straight forward and straightforward e-learning instruments, stages and gadgets can attract more customers so this perspective has been made sure about by various researchers working on the activity of ICT in open and partition learning. Various researchers have tackled this issue and diverse research works have been done on convenience of e-learning gadgets gave by different organizations to their academic ventures.

\section{B. Learner's Accession}

E-learning may be overflowing with central focuses and possible results yet it requires $\mathrm{PCs}$ and web arrange. Computerized segment is a reality and there is a significant gap among made and making countries with respect to development and again there is moreover a sharp division inside the social requests of making countries. Many research works have been done to know the understudies' promotion to the web which is the basic need of elearning. Indian culture is using information, particular mechanical assemblies and progressions at standard with made countries anyway a significant bit of our masses is absolutely limitless to these things.

\section{Artificial Intelligence}

This imaginative example makes e-learning as exceptional things to the world. It is something like programming which is proposed to take some sharp exercises scrutinizing entire condition around it. Computerized reasoning based e-learning structure is a system that have the ability to perform different endeavors requiring human information. It keeps up the ability to make answers for human-related issues, like talk affirmation, understandings 
including different tongues, dynamic, and significantly more.[19][ This can convey a by and large astounding instructor which helps in making each and every understudy an OK ace in their own field. The commitment of electronic thinking in e-learning makes the understudy take sharp decisions and quality resource, which along these lines urges the understudy to surpass desires and make his achievements at speedier stage

\section{Adaptive E-learning}

Versatile e-inclining uses electronic gadgets as an instinctive educating contraption. In light of the improvement of information and correspondence headways in various fields, which have moreover impacted the enlightening fragment, flexible e-learning structures are seen as one of the most fascinating investigation zones in detachment electronic preparing and its bearing engages designers to build a model of targets, tendencies and data on each individual customer in order to change the making sense of how to his/her needs and attributes.[20] Versatile learning system can be executed on the web for use in partition learning and assembling joint exertion. Versatile learning has been executed in a couple of sorts of enlightening structures, for instance, adaptable hypermedia, vigilant coaching systems and mechanized flexible testing. Adaptable e-learning is a rich examination resources and following of understudy by coach or human doled out with spares heaps of time of understudies.

\section{E. Internet of Things (IoT) Based E-Learning}

An IoT based e-learning student is a bit of the learning structure as a substance and constant after of understudy by the system with ceaseless updates to understudies. IoT can be an amazing gadget for the understudies minute learning for like step by step study turns out, step by step news or any information study the understudy immediately plan to learn. IoT permitted to imaginative movements in the frameworks organization with the help of which authentic things can be related with talk with each other over the web. The interconnection of various things over the web with the limit of sending and getting information has a wide number of usages in basically every field like therapeutic administrations, business, transportation, cultivation, the administrators and guidance. [21] Nowadays, for advancement the understudy will be normal like a thing in the whole structure, where the system related will perceive the new revived and express understudy IP and gives all the updates.

\section{F. Video Based E-Learning:}

In video e-learning visual explanation of ideas can conceivable with share more information in less time. Video e-learning urges the understudy to understand the substance by survey the accounts. Right when an understudy needs to get an idea on some specific subject in nuances he visits the site unquestionably for instance
Youtube.com is a rich wellspring of video e-learning substance.

\section{G. Cloud Based E-Learning:}

Cloud-based e-learning configuration supports an enhanced and distinctive learning inclusion in $\mathrm{f}$ ) Intuitive features, for instance, tests and voiceovers that challenge the customer's significance of understanding and level of upkeep by mirroring the customary forward and backward that goes with very close direction. Also, there are a few advantages of cloud based e-learning, for example, staying refreshed, and community learning condition, diminishing costs, data to give and appropriate examination material. It's an open entryway for providers to grow their extension significantly more remote and light an overall learning system without devouring any additional advantages. [22] It is a system encouraged on the web and can be helpfully gotten to by marking into a master center's website page. It is completely done by understudy the official's system, which also empowers the organizer to store information on the cloud, which can be remotely gotten to by other, attested customers.

H. Mobile Based e-learning:

Versatile based e-learning is the limit of an individual to get or give enlightening substance on near and dear pocket devices. Portable based e-learning are seen as best stage for e-learning considering the reality which is anything but difficult to use, potential to show up at masses, conveyed continually, modest and Just in Time (JIT) learning. Mlearning is a trademark development of e-learning and can make learning substantially more by and large open and accessible than we are used to in existing e-learning circumstances. It is inside this setting m-learning can add to the idea of preparing. It offers open entryways for the improvement of association among educators and understudies, among understudies and among people. The activity that correspondence and correspondence play in the learning system is an essential accomplishment factor.

\section{Conclusion}

As the above portrayal, we can say e-learning is a zone of getting ready and creating guidelines and imparting to ICT apparatuses. It incorporates the arrangement, movement of data and rouses understudies to help out each other, similarly as exchange and respect unmistakable reason for points of view. E-Learning is a popular subject for analyze among the investigators from different parts of information and scientists are focusing on the present creative status and future possibilities of e-learning. It has a bigger number of advantages than impediments like it is monetarily sparing, saves time, $24 \times 7$ gets the opportunity to, become acquainted with own getting speed, quick answer of any questions, etc. Its assignment in specific associations has extended faculty and understudy's passageway to information and has given a rich space to 
composed exertion among understudies which have improved insightful standards. All the understudy and guide welcome it and feel extraordinary in using it. Elearning incorporates the usage of cutting edge devices for training and learning. The general composing which explains the focal points and weights of e-learning proposes the necessity for its execution in cutting edge training for work force, administrators and understudies to value the full focal points that go with its choice and use. The vast majority of the authorities are taking e-learning as a potential response for some preparation related issues of making countries like colossal populace, land arranged assortments, budgetary goals for opening schools and universities in enormous numbers and versatility. It uses inventive instruments to engage understudies study at whatever point, wherever and encourages correspondence with improves the associations that keep learning.

\section{REFERENCES}

[1] Uhomoibhi, J. O. 2006. Implementing e-learning in Northern Ireland: prospects and challenges. Published in Emerald Insight Campus-Wide Information Systems, 23, 414.

[2] Jonassen, D.H. (1999), Designing constructivist learning environments, in C.M. Reigeluth (Ed), Instructional design theories \& models, $2^{\text {nd }}$ ed Mahawh NJ:Lawrence Erbaum Associates.

[3] Markus, M. Lynne and Silver, Mark S. (2008) "A Foundation for the Study of IT Effects: A New Look at DeSanctis and Poole's Concepts of Structural Features and Spirit," Journal of the Association for Information Systems: Vol. 9 : Iss. 10 , Article 5.

[4] Olojo Oludare Jethro, Adewumi Moradeke Grace Ajisola Kolawole Thomas,(2012) "E-Learning and Its Effects on Teaching and Learning" in a Global Age International Journal of Academic Research in Business and Social Sciences January 2012, Vol. 2, No. 1 ISSN: 2222-6990.)

[5] Stotz, S., Lee, J.S., Rong, H. and Murray D., (2017). The Feasibility of an eLearning Nutrition Education Program for Low-Income Individuals. Health Promotion Practice, 18(1), pp.150-157.

[6] Klein, D. \& Ware, M. (2003). E-learning: new opportunities in continuing professional development. Learned publishing, 16 (1) 34-46

[7] Algahtani, A.F. (2011). Evaluating the Effectiveness of the E-learning Experience in Some Universities in Saudi Arabia from Male Students' Perceptions, Durham theses, Durham University.

[8] Hameed, S. Badii, A. \& Cullen, A. J. (2008). Effective elearning integration with traditional learning in a blended learning environment.European and Mediterranean conference on information system, (25-26).

[9] Marc, J. R. (2002). Book review: e-learning strategies for delivering knowledge in the digital age. Internet and Higher Education, 5, 185-188.
[10] Wentling T.L, Waight C, Gallagher J, La Fleur J, Wang C, Kanfer A. (2000). E-learning - a review of literature. Knowledge and Learning Systems Group NCSA 9.1-73.

[11] Nichols, M. (2003). A Theory for E-Learning, Educational Technology and Society, Vol. 6, No.2, 1-10.

[12] Smedley, J.K. (2010). Modelling the impact of knowledge management using technology. OR Insight (2010) 23, 233250.

[13] Collins, J., Hammond, M. \& Wellington, J.(1997). Teaching and Learning with Multimedia, London: Routledge.

[14] Almosa, A. (2002). Use of Computer in Education, (2nd ed), Riyadh: Future Education Library

[15] Akkoyuklu, B. \& Soylu, M. Y. (2006). A study on students $^{\text {ee }}$ views on blended learning environment. Turkish Online Journal of Distance Education, 7(3), ISSN 13026488 .

[16] Dowling, C., Godfrey, J. M. \& Gyles N. (2003). "Do Hybrid Flexible Delivery Teaching Methods Improve Accounting Students' Learning Outcomes," Accounting Education:An International Journal, 12 (4), 373-391.

[17] Young, J. R. (1997). "Rethinking the Role of the Professor in an Age of High-Tech Tools," The Chronicle of Higher Education, 44 (6)

[18] Burdman, P. (1998). Cyber U. Anaheim (California) Orange County Register, September 13, sec. 1, p. 9

[19] https://elearningindustry. com/ artificial- intelligencebased- platform- impact- future-elearning]

[20] Soukaina Ennouamani, Soukaina Ennouamani, An overview of adaptive e-learning systems, The 8th IEEE International Conference on Intelligent Computing and Information Systems (ICICIS 2017)( https://www.researchgate.net/publication/322586183)

[21] Zaid AjazMoharkan; Tanupriya Choudhury; Subhash Chand Gupta ; Gaurav Raj ,2017, Internet of Things and its applications in E-learning,IEEE, 3rd International Conference on Computational Intelligence \& Communication Technology (CICT)

[22] https://elearningindustry.com/cloud-based-elearning-5benefits].

[23] Georgieva, T., Georgieva, E., \& Smrikarov, A. (2004). mLearning: A new stage of e-learning. In Proceedings of the International conference on Computer Systems and Technologies (CompSysTech' 2004) (pp. 1-5). Rousse, Bulgaria: CompSysTech

[24] Poona Gaur,(2015),Article on Reseach Trends in ELearning; Media Communique, 1 (1), Pages 29-41,2015; www.researchgate. net/publication/ 306092115

[25] Epignosis LLc, (2014), Book on Elearning:Concept,Trends,Applications, www.efrontlearning.net 